\title{
Research on the Construction and Elements of Integrated Supply Chain Management-An Example of P.G. Logistics Group
}

\author{
Shengjun Zhang \\ School of Business Administration, South China University of Technology, Guangzhou, China \\ Email: joycezhangsj@126.com
}

How to cite this paper: Zhang, S.J. (2018) Research on the Construction and Elements of Integrated Supply Chain Management-An Example of P.G. Logistics Group. Open Journal of Business and Management, 6, 87-102. https://doi.org/10.4236/ojbm.2018.61007

Received: November 20, 2017

Accepted: January 21, 2018

Published: January 24, 2018

Copyright (c) 2018 by authors and Scientific Research Publishing Inc. This work is licensed under the Creative Commons Attribution International License (CC BY 4.0).

http://creativecommons.org/licenses/by/4.0/

\section{(c) (i) Open Access}

\begin{abstract}
The construction of service mode is the key to the formation and development of the logistics enterprises' core competitiveness. Especially in the context of integrated supply chain, how to effectively build and promote the innovative service mode is the core issue of logistics enterprises' survival. Therefore, recognizing the driving forces of logistics enterprises in service mode reform and establishing a proper organizational structure which promotes innovative elements are a constant that needs for further research. Based on the China domestic and international research on the related theories of supply chain integration, this paper puts forward the construction and elements of the supply chain integrated service mode and makes a single case study. The core content of this mode and its application in practice is the driving forces behind the integrated supply chain service mode and the relationship between service mode elements and its governance.
\end{abstract}

\section{Keywords}

Supply Chain Integration, Service Mode, P.G. Logistics Group, Case Study

\section{Introduction}

Supply chain integration refers to the degree to which an organization's activities are integrated with the activities of its suppliers, customers, and other firms in its supply chain [1]. Integration makes the upstream, middle and downstream enterprises reach to the logistics enterprises. And customers can also be integrated, in the absence of a clear ownership, in the form of a unified, collaborative entity to conduct business operations [2]. The existing research shows that supply chain integration has a positive effect on business performance [3]. In today's 
increasingly competitive market, turbulent environments are leading supply chain management into the era of supply chain integration [4], enabling enterprises to enjoy the dividends brought by the integrated operation of business flow, logistics, information and capital flow. Especially in recent years, with the rapid development of the mobile Internet many industries are greatly impacted and challenged, and the traditional supply chain management mode has been difficult to adapt to high-frequency interaction among enterprises, a large number of information exchange and customer demand for personalized products. Supply chain Integration is becoming one of the core competencies that companies must own in response to market demands.

At the same time, the trend of supply chain integration puts forward higher requirements on the services provided by logistics enterprises. On the one hand, clients want to focus on their own core competitiveness building so give more expectation that their logistics cooperation partner company can act as an "expert" on the entire enterprise logistics process and put forward solution packages to the problem. On the other hand, with the increasingly fierce competition in the traditional industries many enterprises put efforts in reducing costs, and the storage and transportation costs often become the primary target for them. As a result, the overall profits of the logistics industry are becoming increasingly diluted. In order to meet the changing needs of the market, the integrated supply chain service mode can not only become the new profit source of logistics enterprises, but also help the transformation and development of logistics enterprises, which has a bearing on its survival. In this context, enterprises and logistics companies create an integrated supply chain service platform to provide online and offline integrated services has become a trend. With such multi-industry linkages, logistics company's business has extended from transportation, warehousing and distribution to high-value-added businesses such as centralized purchasing, inventory management, information management, system design and personalized and innovative business development [5].

However, the current literature on supply chain integration mainly focuses on the different dimensions of supply chain integration and the core enterprises in the supply chain [6] [7], and does not pay attention to the impact of supply chain integration on logistics enterprises; the research on logistics enterprises mainly focuses on the logistics organizations' evolution such as the "fourth-party logistics mode" [8], and seldom focuses on how to deal with integration of supply chain. The inability to meet the needs of customers in the trend of supply chain integration is an important external influencing factor for the evolution of logistics organizations. It brings pressure to the development of logistics enterprises as well as provides impetus. Therefore, focusing on the construction of an integrated supply chain service mode will help to clarify the evolution process and direction of logistics organizations, and provide new ideas for logistics organization evolution process research. Therefore, based on the research gap, the main goal of this paper is to explore the construction of logistics service mode 
and its components under the background of supply chain integration. The main research questions are as follows:

1) Facing the market and its own development needs, how should the logistics company accomplish the strategic transformation from traditional service supplier to supply chain integrated service mode supplier? How to build an integrated supply chain service mode?

2) What are the content and key elements of supply chain integrated service mode? What is the connection between them? What can we learn from benchmarking practices?

\section{Literature Review}

\subsection{Connotation of Supply Chain Integration}

Supply chain integration refers to the degree to which an organization's activities are integrated with the activities of its suppliers, customers, and other firms in its supply chain [1]. Due to the gradual increase of outsourcing business proportion, the globalization of the supply chain and the shortening of the product life cycle, the production and operation activities of enterprises begin to face higher risks [9]. These risks make enterprises' supply chain more complex than before, so they begin to strategically cooperate with other key links such as suppliers, customers and so on to meet their own competition and development needs. Supply chain integration is one of the key ways for supply chain management to create value for enterprises. Some scholars believe that supply chain integration includes only one dimension, but most scholars believe that supply chain integration should include multiple dimensions. The more common view is that supply chain integration consists of three main dimensions: internal integration, customer integration and supplier integration, of which the latter two may also be collectively referred to as external integration [10] [11] [12] [13].

Supply chain integration is an inevitable trend about the development of China's circulation of commodities, and the choice of logistics mode is one of the important carriers that enterprises face. Enterprises hope that the logistics company can put forward a package solution and act as an "expert" to carry out the overall planning and integrated operation of the logistics network. With the help of logistics management and technology advantage, the company will complete its work cooperated with suppliers, manufacturers, distributors, retailers and consumers, within an accurate and rapid logistics process. This integrated service supply chain mode allows logistics companies to take advantage of their own resources in the field of logistics and reduce the supply chain operating costs [14], thereby help their clients save capital and energy to invest into their main business, and fully realize the benefits maximization.

However, the integrated supply chain mode construction will bring considerable challenges for the technical and professional capabilities of logistics enterprises [15]. Only with a comprehensive basic logistics facilities, a high level of storage capacity, a sound information system and management capabilities can 
the logistics company complete the integrated logistics distribution operations and improve logistics efficiency and quality. At the same time, the construction of this mode of service poses new requirements on enterprises strategy, talent and management.

\subsection{The Construction and Elements of Supply Chain Integrated Service Mode}

\subsubsection{The Structure of Supply Chain Integrated Service Mode}

On the one hand, in order to maintain a competitive advantage and achieve sustained profit growth, the integrated supply chain mode requires that the relationship between companies and external supply chain members be closer than ever before in different functions within the logistics company [16]. On the other hand, all aspects of the operation of logistics enterprises involve several stakeholders, and enterprises must balance their interest demands in order to obtain the necessary resources from them. Logistics enterprises can enhance the utilization of internal and external resources through different modes of integrated supply chain services. These service modes will involve such as business processes strategic alliances, information sharing, and collaborative work [17]. There are three major types of integrated service modes: chain, network and community.

One of the main dimensions of supply chain integration is supplier integration. Therefore, suppliers will undoubtedly have an impact on the service mode of logistics enterprises. Similarly, customers also play an important role in the supply chain integration service mode. This innovative approach to service integration from suppliers (i.e., sub-service providers) to customers and upstream and downstream businesses is defined as chained. Some studies on the nature of supply chain relationships, which take supply chain integration as a result of the relationship between customer and supplier [18], and the success of such a relationship and the resulting competitive advantage can be affected by a complex set of factors, Including corporate strategy, business-to-buyer understanding, product customization, technology, etc. [19] that the effectiveness of supply chain relationships is influenced by the organization's ability and supply chain partners' effective identification of their integrated mechanisms.

The main body of the logistics enterprises, the joint external network of interconnected businesses, universities, research institutions, government, financial institutions and other value network stakeholders to participate in the supply chain integration service mode is defined as the network. The implication of this approach is that at the process level, the supply chain integrated service mode can be exploited to explore the processes shared by other stakeholders or to test the development of new service modes other ways to achieve [20]. One possible way to achieve supply chain integration is to break down the project flow for the development of new service modes, formally release from the creation of mode ideas to service modes, and explore the extent to which third parties participate and collaborate at different stages. The formation mechanism of 
the supply chain integrated service mode relies on the different departments and teams that cooperate with the external organizations. The teams with different or different functions and the cooperation with the outside world can support the incremental innovation of the existing modes, and the functions and the diversity of the team can also support the fundamental innovation of the new service mode [21]. Research has also proved that the integration of $\mathrm{R} \& \mathrm{D}$ team and purchasing team can affect the cooperation between the enterprise and external third parties [22]. Therefore, different functional teams should share different roles in supply chain integration and have different roles.

The structure of industry-based subdivision level collaboration with business innovation is defined as group type. Porter argues that industrial clusters apply not only to manufacturing but also to services [23]. Studies have shown that integrated supply chain management also promotes collaboration and integration among members of different supply chains within specific industries [24]. Many scholars have studied the logistics industry cluster and explored the competitive advantage formed by the aggregation of logistics enterprises [25]. Through forming some kind of supply chain cooperation, enterprises share the task of providing integrated services for other industries, so that not only Can take on the logistics service separated by other industries and can also exert its own core competitiveness correspondingly so as to optimize the long-term operation efficiency and operation cost of the integrated supply chain mode.

\subsubsection{The Content of Supply Chain Integrated Service Mode}

In the study of business mode elements, Heikkila et al. Argue that the elements of the business mode mainly include consumers, services, organizations, finance and technology. The combination of business-to-business elements is based on the differentiated use of resources based on effective understanding of customer value and ability [26]. According to the theory of resource-based view, the competitive advantage of enterprises comes from the construction of heterogeneous resources, which must have the characteristics of value, scarcity, non-imitation and irreplaceable. The integration of resources is the core of the supply chain integrated service mode. The service mode collects these resources through the coordination of all participants and aggregates the resources in the industrial chain so as to realize the enterprise performance. Vargo and Lusch argue that there are two forms of resources and one is operand resources, that is, tangible and static resources that often need to be made valuable by taking certain actions. The other is operant resources, that is, the ability to have the initiative, knowledge, wisdom and other hidden things. Supply chain integration service mode is based on the customer's value demands, relying on these two different resources to build the corresponding service form [27].

Based on the types of resources used by logistics enterprises, this paper divides the contents of supply chain integrated service mode into three forms: business process oriented service, customized technology service and system integrated package service. Business Process Oriented Services refer to suppliers that add 
value to their customers' value by integrating business activities into customer service value chains or business processes, such as taking over management activities, order fulfillment activities, or logistics activities of clients [28]. To be operational resources as the center, with service-supplemented business processes to meet customer needs, thereby reducing the total operating costs. Technical Application Customized service is a customized technical service based on operational resources. It requires that enterprises flexibly respond to the demands of customer differentiation and dynamization, and provide technical solutions according to the specific needs of customers [28]. System Integration Packaged Services refers to the enterprise through the integration of resources, capabilities and knowledge to meet all customer requirements for a particular event or issue the value of the demand. System Integration Packaged services emphasize "packaging" and "system integration" [29]. "Packaging" refers to a package of resources that provide both operational and operational resources. "System integration" refers to the realization of overall value by providing a total solution.

\subsubsection{The Governance of Supply Chain Integrated Service Mode}

Another issue related to the construction of an integrated supply chain mode is the governance of service modes. The governance of service mode includes the internal governance mechanism and the external governance mechanism of enterprises. Anoop divides the structure of transactional governance among organizations into two types: contract-centered governance structure and relationship centered governance structure [30]. Ronald et al. Proposed two effective mechanisms for studying the governance mode of interorganizational transactions: contract governance and relationship governance [31]. Contract governance is mainly applied to planned transactions, which is a market governance structure that can be adopted for contingent or recurring transactions under non-asset-specific conditions, also known as the classical contract law governance structure. The terms of the contract already set out the substantive content of the transaction and comply with the principle of law, so such contracts undoubtedly benefit the person who performs the law. Corresponding to the contractual governance, relational governance refers to an inter-organizational transaction mode that includes the main relationship-specific assets, which is embodied in the dimensions of the structure and process of inter-organizational relationships, emphasizing that relationship governance is an informal vertical transaction Process [32].

In summary, the logistics enterprises in the face of fierce market competition and changes in customer needs transformation and upgrading must be based on knowledge integration to try innovative service mode construction, through chain, network, group, such as the integration of different ways The internal and external resources to be utilized, and in building these elements of the service mode based on the development of a series of services to customers, the process of internal and external relations to control and governance, through the integrated supply chain mode to achieve business transformation, and then to Busi- 
ness performance has improved.

\section{Research Method}

In order to illustrate how to construct the integrated service mode of supply chain and which elements are involved, this article has conducted a multi-level analysis of P.G. Logistics, using a single case study method, choosing P.G. Logistics as a typical case to explore its series of changes. The advantages of a single case lie in its ability to go deeper into research and analysis, and random cases are sometimes not desirable for case-based approaches, and it is more appropriate to choose between typical and extreme cases.

P.G. Logistics was established in 1994, mainly to provide customers with supply chain integration of professional logistics services, is currently China's largest and influential logistics companies. For the logistics from the creation of the Department to provide customers with door-to-door integration services to build integrated supply chain now service strategy, its development has gone through three stages. In the first stage, from 1994 to 1997, P.G. Logistics was transformed from a traditional storage and transportation enterprise into a specialized company providing integrated logistics services. In the second phase, from 1997 to 2000, Pohjong gradually developed into a relatively mature of the third-party logistics enterprises; the third stage, since 2000, P.G. Logistics restructured the supply chain integrated logistics services, and achieved good results. In the third stage, P.G. Logistics upgraded its own infrastructure, information systems, personnel management and development strategies and many other aspects, the successful implementation of the integrated supply chain management mode, creating a leading logistics industry's core competitiveness. So, how is P.G. Logistics building its unique service mode to complete the business transformation and occupy the market leading position in the industry? What are the content and core elements of its integrated supply chain mode? In this paper, we hope to provide a reference for other logistics enterprises to build an integrated supply chain management mode through an in-depth analysis of the case of P.G. Logistics, and revealing its benchmarking and success.

The materials and data for the study of logistics service mode come from many aspects. First, it comes from the research and in-depth interviews with P.G. Logistics, including the chief managers, chief business executives and front-line employees of P.G. Logistics for Physics, and secondly, Tripartite research reports (foreign) and industry analysis reports; once again come from Po for the annual report, financial statements and internal management system, the year-end summary report, the leadership speech material.

\section{P.G.L Service Mode}

\subsection{Supply Chain Integration Service Mode Development Forces}

\subsubsection{The Challenge of Traditional Service Mode}

For the logistics industry, the traditional service mode is facing an increasing 
threat. First of all, it is an indisputable fact that the overall profits of the logistics industry are becoming increasingly diluted. With the increasingly fierce competition in the traditional industries, these enterprises have been working hard to reduce costs in order to gain a competitive edge. In many cases, the cost of storage and transportation has become their primary goal. On the other hand, many enterprises lack the overall planning of the whole process of logistics from the upstream raw material suppliers, their own internal production processes to the downstream warehouse distributors, the carriers until the retailers and so on. As a result, compression costs have caused the overall cost of rising things have occurred, many companies are paying the high cost of supply chain issues. In addition, as the professional division of labor is refined, more and more enterprises are beginning to focus their energies on their core competencies. In addition to the development of major technologies and the production of major product components, more and more businesses are being outsourcing, they are willing to spend the upper reaches of raw materials procurement and downstream product sales part of the energy is also less. Under such circumstances, they also hope that the logistics companies that cooperate with them will be able to provide a professional solution to their entire logistics system in a package instead of requiring them to worry about these problems. These are driving the logistics enterprises closer to the supply chain integration.

At the same time, supply chain integration is leading traditional enterprises to more extensive integration, which is generally considered to have a positive impact. The integration of cross-business customers and suppliers can accelerate information sharing and decision-making and ultimately form a sustainable competitive advantage that may include both technical and traditional enterprise promotion with its customers and suppliers [33]. These different dimensions are conducted in different ways, while the degree of strategic cooperation between traditional enterprises and supply chain partners is different, and the process of collaborative management of internal and external organizations is different [13]. When logistics enterprises provide services to such enterprise customers, logistics solutions may need to be tailored to the integration of all aspects [34].

\subsubsection{Industrial Process Decomposition and New Service Development} At the process level, logistics companies need to integrate customer needs and translate ideas about the new service mode into tangible new services. This process often involves cross-organizational issues. The supply chain integrated service mode helps to coordinate the tasks among different enterprise members in the industrial chain and plays a very important role in the development of new services. With the supply chain integrated service mode, logistics service providers, other service provider companies and customer companies are closely linked to the new service development process. In particular, key point design and control can be achieved through a clear process interface. And steps to communicate and collaborate. In this way, effective task coordination is accomplished, reducing wasted effort and redundancy in managing supply chain activ- 
ities, making knowledge exchange and knowledge discovery more efficient. This ability to coordinate and partner with suppliers has been demonstrated to improve the service experience, market success of service innovation, and the reduction of new service development time [16].

\subsubsection{Experiential Management and the Change of Value Demands}

In a market environment, exchange of value is seen as a central goal of economic exchange [35]: Corporations provide value propositions in the form of services, and thus experience becomes crucial when customers use these services [36]. Service-oriented logic believes that customers are always co-creators of value, and customer perceived value is the core of service. This re-understanding of the value objectively requires that the service mode of enterprises be fundamentally adjusted, and experiential management becomes more and more important to service-oriented enterprises.

To sum up, the supply chain integration service mode emerged in the process of transformation. At the same time, P.G Logistics has developed its own strategy of building long-term competitiveness by providing integrated supply chain services. The integrated management capabilities of the supply chain make it possible for the originally independent logistics segments to cross each other, thereby enhancing collaboration among different divisions of the enterprise and with other supply chain members [37]. In the development of the new service mode, the integration of supply chain helped P.G. Logistics to establish mutual trust with other cooperative enterprises and to promote the acquisition of information through network relations [38]. In particular, the market-oriented supply chain integration mechanism helps P.G Logistics acquire knowledge about customer needs, and through the integration of the upstream value chain, supply chain integration will share this knowledge and service mode design requirements with other service providers, allowing other service providers to participate in the development of new service modes while also giving Plover possibilities to enhance its internal capabilities [39].

\subsection{The Structure of P.G.L Supply Chain Integration}

\subsubsection{IT Technology}

Supply chain integration service mode is a high-performance business mode, P.G. Logistics strove for the integration of resources through this service mode, specifically through the IT technology-driven, integrated innovation. As far as the IT technology is concerned, as early as 1997, P.G Logistics took the lead in implementing the logistics information management system based on Internet / Intranet among similar enterprises in the country. By virtue of this system, P.G Logistics has realized the real-time dynamic tracking of the logistics operation information nationwide management. Since then, P.G. Logistics invested more than 10 million Yuan to improve and upgraded the system, achieved customer's electronic data exchange through this system, and provided customers such as reporting, operational advice and other personalized logistics information ser- 
vices, therefore, business between P.G. Logistics and customers becomes more convenient and efficient.

On the other hand, P.G. Logistics has set up its branch offices in the central cities in the country in order to realize its transformation into a supply chain integrated service provider, laying a national network based on this. Especially in recent years, P.G. Logistics has begun to provide value-added supply chain integrated logistics services in the direction of the logistics base as an important breakthrough in improving supply chain service capabilities. In addition to increasing the number from the original 10 to 15 , these logistics bases will also be built into a one-stop logistics center integrating distribution, sorting, assembling and simple processing functions. At the same time, it also provides such functions as bonded goods, customs clearance, inspection and quarantine and international financial settlement based on import and export business. In addition, since the products of the manufacturers and suppliers are distributed at the base of P.G. Logistics, the base is also a purchasing platform. With these bases, for customers to reduce a large number of handling links, reducing logistics costs, itself through value-added services for more profits. Through the construction of logistics base to create small batch, batch, variety of delivery and rapid response capabilities, all aspects of the logistics highly integrated and efficient, is the treasure for supply chain integration service provider transformation is important Vector. Further, P.G. Logistics expects to establish branches or offices in major cities based on the logistics base, establish a strong and comprehensive network of logistics operations, and widely integrate logistics services such as warehousing, transportation, packaging and distribution as Customer "tailor-made" to provide "door-to-door" integrated integrated services and other value-added services.

\subsubsection{Chain Structure}

P.G. Logistics chain for the integration of supply chain mode building specifically for the performance of two aspects: First, the integration of operational resources, such as invest huge sums of money in Guangzhou, Shanghai, Suzhou, Hefei and other places to build large-scale logistics base; the second is the process Design, P.G. Logistics build a complete and strict operation management system and quality assurance system to ensure that customers provide high quality and efficient professional logistics services. In order to plan the operation standard of the business department, P.G. Logistics has established a systematic and standardized operate procedures, namely SOP standard operating procedures. SOP have detailed rules for any matter in any position. With the correct implementation of SOP, it is ensured that the operation of the business will not result in any difference in service quality due to personal factors. In 1996, P.G. Logistics based its GMP quality. Based on the 13 key requirements of GMP, P.G. Logistics formulated a set of corresponding serialized quality management standard system, compiling the specific standard and timely requirements for each element into Quality Management Manual. At the same time, the company set 
up a quality management department at the headquarters of the company to implement and implement the Quality Management Manual so that each operation will have quality control and follow-up from the beginning of the operation so as to fully guarantee the stable and reliable operation of the business. In addition, the company also vigorously promote the "emphasis on quality, management", requires that every employee establish a clear sense of quality, everyone has quality responsibility, make GMP as a treasure for the brand image.

\subsubsection{Network Structure}

The network construction of the integrated supply chain mode relies more on the corporate network. The purpose of such a network is to share knowledge, the second is to coordinate the value of the appeal, so to establish multi-party cooperation and trust with the external relationship is the key. To be specific, Treasurer focuses on improving the quality of staff on one hand, inviting experts to join, enriching staff in logistics planning and implementing its personnel training program to deepen employees' understanding of the supply chain- "Polaris Project" Make knowledge network established. On the other hand, it has actively formed a multi-dimensional cooperative relationship with external resources and sought to create conditions for the transformation of integrated supply chain services from the outside. For example, since 1997, P.G. Logistics has been cooperating with Beijing Technology and Business University to hold an annual "Advanced Seminar on Logistics Technology and Management Development", inviting domestic and international logistics experts and some customer representatives to make suggestions for the development of China's logistics industry with a view to expanding logistics Intra-industry information and communication. In 2000, P.G. Logistics set up China's first venture funded by enterprises of the logistics field, an annual investment of 1 million Yuan for reward science and technology. So the company made important contributions to the groups and individuals of China's logistics industry.

\subsubsection{Community Structure}

Another important aspect of the construction of P.G. Logistics for supply chain integrated service mode is group mode. This approach refers to the value-added, high technology content, product-related advantages of strong enterprises and superior products as the chain of nuclear, nuclear chain through these products to the service as a link to the capital, before and after the formation of contact with the community. Group-based service mode and service supply chain covered almost all supply chain activities. Horizontal, for the implementation of alliance development strategy from 2000, P.G. Logistics emphasized the supply chain nodes embedded between complementary advantages and benefit-sharing symbiotic relationship. P.G. Logistics widely find strategic partners through the alliance to gain a competitive advantage for other third-party logistics companies, customer service groups, related industries. At the end of 2013, in response to the new normal in China and the new market trend, and in the wake of the 
major changes and major changes brought by the fourth industrial revolution led by intelligent manufacturing, P.G. Logistics formulated the "four-wheel drive and two-wing take-off" The Group will continue to build its logistics integration capabilities by positioning the future Polar Logistics Group as a smart headquarters and as a provider of logistics integration solutions for large industrial and commercial enterprises and as an implementer of third-party logistics. In 2014, P.G. Logistics announced two platforms targeting the "Fortune 500" in the third party, including two platforms for Expressway Express and Logistics Resource Trading-Po Express, Service, so that more and more small and medium-sized micro-enterprises to enjoy the world's top 500 standardized logistics services.

Vertically, in April 2014, P.G. Logistics announced cooperation with IBM to provide enterprises with supply chain integration solutions and accelerated the pace of strategic transformation from third-party logistics enterprises to supply chain service providers. The cooperation between IBM and P.G. Logistics is expected to use IBM's advantages in information technology to jointly cut into the market of supply chain services. As Head of Logistics for Logistics Department, P.G. Logistics said: "Our cooperation with IBM is called a god and a land. For IBM, their technology and tools have been brought to fruition by working with us; and for us, working with IBM has made our services better."

\section{Conclusions}

Through the above case study of P.G. Logistics, we found that the formation and operation of the integrated supply chain mode provide a new and worthwhile reference for other logistics enterprises in our country and related service enterprises. By integrating this service mode, service providers plan, structure, factor, and manage the structure of business, information, and cash flows to create, deliver and realize value for their customers. Through case studies, we can get the following conclusions:

First of all, the starting point of the service mode system thinking lies in the strategic positioning of the enterprise. The choice of service mode means that companies need to think about what activities or processes can enhance the value of their customers. In response, companies need to think about why they choose not to do other activities. The significance of exploring this issue is to better understand the original intention of enterprises to choose a service mode, that is their own positioning. It can be seen from the examples provided by P.G. Logistics that although each shift is only a small step, they all develop along the established direction with definite principles and standards.

Second, the service mode is the diversification of management and service content for multiple stakeholders. The case study shows that due to the diversity of participants in service-oriented supply chain, it is bound to result in interactive value understanding or diversification. Such values include primary value, induced value and social value. The primary value is an important factor in faci- 
litating the transaction [40]. It is the economic value that can be directly assessed using quantitative criteria, such as the trading of products, services and other exchange goods. The induced value is the result of the ongoing trading relationship in the future or forward transfer of the value generated, the most direct manifestation of it is the continuation of the relationship; social value through their own and self-practical activities to meet the social and other people's material and spiritual needs to make their contribution and responsibility, this value embodies the social citizen role of each participant and promotes the formation of commercial ecosystem. It is this diverse value and orientation that drives the formation of service modes and creates complex and multi-level interactions among stakeholders. Therefore, the success of a service mode depends largely on the ability to handle the value demands of different stakeholders.

Furthermore, innovating the organizational structure and governance mechanism. The choice of a service mode also requires a corresponding organizational structure and governance mechanism to ensure the effectiveness of this service mode to its fullest extent. Every time the service mode changes, P.G. Logistics will make corresponding adjustments in the organizational structure and governance mechanism, and some may even jump. In fact, exploring the organizational structure and governance mechanism has always been a question that needs thinking. For example, whether the establishment of a group structure depends entirely on strategic alliances. In addition, as customers increasingly demand that they take control of the industry value chain, how service integrators can effectively consolidate resources, provide differentiated service content, and manage these changes to their management structures should also be taken into account.

Finally, the innovation of service mode is a dynamic process whose purpose is to enhance the value of the enterprise. Although the system of service mode has never been explored domestically and internationally, I think that the management situation theory is applicable to the innovative design of service mode. Enterprises should choose one based on "national conditions", "market conditions" and "business conditions" Suitable for their own service mode. Once the environment has changed, but also need to change the corresponding service mode, that is, the innovation of service mode is a dynamic process of development. The transformation of P.G. Logistics service mode every time is based on the original activities of the integration or increase, the results show that this approach not only created more value, but also attract more customers and increase the value of the enterprise.

\section{References}

[1] Shou, Y., Li, Y. and Park, Y.W. (2017) The Impact of Product Complexity and Variety on Supply Chain Integration. International Journal of Physical Distribution \& Logistics Management, 47, 297-317. https://doi.org/10.1108/IJPDLM-03-2016-0080

[2] Liu, L. and Song, H. (2014) Innovation Framework and Key Elements of the Servitization Business Model. Journal of Management Case Studies, 7, 22-33. 
[3] Yao, M., Wu, X., Shi, Y., et al. (2014) The Fit, Based on the Perspective of the Technological Catch-Up, between the Business Model Design and the Technology Innovation Strategy: A Multi-Case Study. Management World, No. 10, 149-188.

[4] Xiao, J., Xie, K., Wu, Y. et al. (2015) The Supply Chain Transformation from Being Partner-Oriented to Being Customer-Oriented: A Double-Case Study on the Supply Chains in Ecommerce Enterprises. Management World, No. 4, 137-188.

[5] Yang, Y., Wang, J. and Liu, L. (2016) Trend and Countermeasures of China's Logistics Industry Development in New Normal Situation. China Transportation Review, 38, 61-66.

[6] Weng, X. (2017) Some Reconsideration on the Characteristics and Innovative Development of China's Logistics Industry. China Business and Market, 31, 8-15.

[7] Li, S. (2011) Study on 3PL Value Added Service Requirement Based on Integration of Supplier Chain. Logistics Engineering and Management, 33, 64-65.

[8] Li, G. and Zhang, M. (2015) Study on the Construction of Logistics E-Commerce Platform under the Integration of Supply Chain. Value Engineering, 34, 24-25.

[9] Zhao, L., Huo, B., Sun, L., et al. (2013) The Impact of Supply Chain Risk on Supply Chain Integration and Company Performance: A Global Investigation. Supply Chain Management. An International Journal, 18, 115-131. https://doi.org/10.1108/13598541311318773

[10] Narasimhan, R. and Jayaram, J. (1998) Causal Linkage in Supply Chain Management: An Exploratory Study of North American Manufacturing Firms. Decision Science, 29, 579-605. https://doi.org/10.1111/j.1540-5915.1998.tb01355.x

[11] Narasimhan, R. and Kim, S.W. (2002) Effect of Supply Chain Integration on the Relationship between Diversification and Performance: Evidence from Japanese and Korean Firms. Journal of Operations Management, 20, 303-323. https://doi.org/10.1016/S0272-6963(02)00008-6

[12] Swink, M.L., Narasimhan, R. and Wang, C. (2007) Managing beyond the Factory Walls: Effects of Four Types of Strategic Integration on Manufacturing Plant Performance. Journal of Operations Management, 25, 148-164. https://doi.org/10.1016/j.jom.2006.02.006

[13] Flynn, B.B., Huo, B. and Zhao, X. (2010) The Impact of Supply Chain Integration on Performance: A Contingency and Configuration Approach. Journal of Operations Management, 28, 58-71. https://doi.org/10.1016/j.jom.2009.06.001

[14] Chen, C. and Sheng, X. (2014) The Evolutionary Game of the Upgrading of the Regional Logistics Industrial Cluster under the Integration of Supply Chain. Science and Technology Management Research, 34, 131-139.

[15] Song, H., Yu, K. and Chen, J. (2013) Service Supply Chain Operation in Different Situations-B2B Multi-Case Study Driven by Resources and Environment. Management World, No. 02, 156-168.

[16] Christina, W.Y., Wong, Chee, Y.W., et al. (2013) The Combined Effects of Internal and External Supply Chain Integration on Product Innovation. International Journal Production Economics, 146, 566-574. https://doi.org/10.1016/j.ijpe.2013.08.004

[17] Dröge, C., Vickery, S.K. and Jacobs, M.A. (2012) Does Supply Chain Integration Mediate the Relationships between Product/Process Strategy and Service Performance? An Empirical Study. International Journal of Production Economics, 137, 250-262. https://doi.org/10.1016/j.ijpe.2012.02.005

[18] Athaide, G.A. and Klin, R.R. (2009) Managing Seller-Buyer Relationships during New Product Development. Journal of Product Innovation Management, 26, 
566-577. https://doi.org/10.1111/j.1540-5885.2009.00681.x

[19] Ahn, H. (2001) Applying the Balanced Scorecard Concept: An Experience Report. Long Range Planning, 34, 441-461. https://doi.org/10.1016/S0024-6301(01)00057-7

[20] Tsinopoulos, C. and Al Zu'bi, Z.B.M.F. (2012) Clockspeed Effectiveness of Lead Users and Product Experts. International Journal of Operations \& Production Management, 32, 1097-1118. https://doi.org/10.1108/01443571211265710

[21] Sun, M. and Hu, J. (2006) Customer Identification and Management under Supply Chain Integration. Soft Science, No. 5, 59-62.

[22] Brattström, A. and Richtnér, A. (2014) Good Cop-Bad Cop: Trust, Control and the Lure of Integration. Journal of Product Innovation Management, 31, 584-598. https://doi.org/10.1111/jpim.12115

[23] Michael, P. (1990) The Competitive Advantage of Nations.

[24] Yang, Y. (2017) The Study of Transformation from Traditional Third Party Logistics to Lead Logistics Provider. Logistics Engineering and Management, 39, 38-40.

[25] Zhang, L. and Zhao, G. (2014) Influence Factors and Action Mechanism of Supply Chain Technology Spillover: A Multi-Case Study Based on the Self-Organizing Process of Supply Chain. Journal of Management Case Studies, 7, 181-194.

[26] Heikki, J., Heikki, M. and Tinnil, M. (2005) The Role of Business Modes in Developing Business Networks. In: Saarinen, T., Tinnila, M. and Tseng, A., Eds., Managing Business in a Multi-Channel World: Success Factors for E-Business, Idea Group, Inc., Hershey, 281-294.

[27] Vargo, S.L. and Lusch, R.F. (2008) From Goods to Service(s): Divergences and Convergences of Logics. Industrial Marketing Management, 37, 254-259. https://doi.org/10.1016/j.indmarman.2007.07.004

[28] Matthyssens, P. and Vandenbempt, K. (2008) Moving from Basic Offering to Value-Added Solutions: Strategies, Barriers and Alignment. Industrial Marketing Journal, 37, 316-328. https://doi.org/10.1016/j.indmarman.2007.07.008

[29] Strmersch, S., Wuyts, S. and Frambach, R.T. (2001) The Purchasing of Full-Service Contract: An Exploratory Study within the Industrial Maintenance Market. Industrial Market Management, 30, 1-12. https://doi.org/10.1016/S0019-8501(99)00090-5

[30] Anoop, M. (1994) Opportunism and Trust in Joint Venture Relationship: An Exploratory Study and Mode. Scandinavian Journal of Management, 11, 57-74.

[31] Ronald, J.F., Michele, P. and Jasmin, B. (2005) Contractual Governance Relational Governance, and the Performance of Interfirm Service Exchanges: The Influence of Boundary-Spanner Closeness. Journal of the Academy of Marketing Science, 33, 217-234.

[32] Zaheer, A. and Venkatraman, N. (1995) Relational Governance as an Interorganizational Strategy: An Empirical Test of the Role of Trust in Economic Exchange. Strategic Management Journal, 16, 373-392. https://doi.org/10.1002/smj.4250160504

[33] Eisenhardt, K.M. (1989) Building Theories from Case Study Research. Academy of Management Review, 14, 532-550.

[34] Christos, T. and Carlos, M. (2015) Supply Chain Integration Configurations: Process Structure and Produce Newness. International Journal of Operations \& Production Management, 10, 1437-1459.

[35] Li, W. (2011) Study on the Relationship between Collaborative-Business Supply Chain Integration and Firm Performance. Soft Science, 25, 103-107.

[36] Vargo, S.L. and Lusch, R.F. (2004) Evolving to a New Dominant Logic for Marketing. Journal of Marketing, 68, 1-17. https://doi.org/10.1509/jmkg.68.1.1.24036 
[37] Zhang, C., Gunasekaran, A. and Wang, W.Y.C. (2015) A Comprehensive Mode for Supply Chain Integration. Benchmarking: An International Journal, 22, 1141-1157. https://doi.org/10.1108/BIJ-05-2013-0060

[38] Veera, P.K.S., Chandran, V.G.R. and Muhammad, A.B. (2016) Supply Chain Practices and Performance: The Indirect Effects of Supply Chain Integration. Benchmarking: An International Journal, 23, 1445-1471.

[39] Revilla, E. and Villena, V.H. (2013) Knowledge Integration Taxonomy in Buyer-Supplier Relationships: Trade-Offs between Efficiency and Innovation. International Journal of Production Economics, 140, 854-864. https://doi.org/10.1016/j.ijpe.2012.07.002

[40] McLoughin, D. and Horan, C. (2000) Business Marketing: Perspectives from the Markets-as-Networks Approach. Industrial Marketing Management, 29, 285-292. https://doi.org/10.1016/S0019-8501(00)00106-1 